25. Raul F, Noriega R, Ngi-Emvo E, Doffoel M, Grenier IF 1983 Lactase activity is under hormonal control in the intestine of adult rat. Gut 24:648-652

26. Koldovsky O. Herbst JJ, Burke J. Sunshine P 1970 RNA and DNA in intestinal mucosa during development of normal and cortisone-treated rats. Growth $34: 359-367$

27. Hatch TF, Lebenthal E, Branski D 1979 Effect of early postnatal acquired malnutrition on intestinal growth, disaccharidases and enterokinase. $J$ Nutr $109: 1874-1879$

28. Lebenthal E, Sunshine P. Kretchmer N 1973 Effect of prolonged nursing on the activity of intestinal lactase in rats. Gastroenterology $64: 1136-1141$

29. Lebenthal E. Sunshine P, Kretchmer N 1972 Effect of carbohydrate and corticosteroids on activity of $\alpha$-glucosidases in intestine of the infant rat. $J$ Clin Invest $51: 1244-1250$

30. Solimano G, Burges EA, Levin B 1967 Protein-calorie malnutrition: effect of deficient diets on enzyme levels of jejunal mucosa of rats $\mathrm{Br} J$ Nutr 21:5568

31. Nsi-Emvo E, Raul F 1984 Stimulation of lactase synthesis induced by starvation in the jejunum of adult rat. Enzyme 31:45-49

32. Scott J, Batt RM, Maddison YE, Peters J 1981 Differential effect of glucocorticoids on structure and function of adult rat jejunum. Am $J$ Physiol 241:G306 G312

\title{
Age-Related Changes in the Adrenergic Control of Glycogenolysis in Rat Liver: The Significance of Changes in Receptor Density
}

\author{
JOHN L. BENDECK AND AKIHIKO NOGUCHI \\ Pediatric Research Institute, Cardinal Glennon Children's Hospital, Department of Pediatrics, St. Louis \\ University, Saint Louis, Missouri 63104
}

\begin{abstract}
The present study examined the developmental changes in the adrenergic control of glycogenolysis in the rat model. A relatively new $\beta$-adrenergic radioligand, ${ }^{125}$ I-iodocyanopindolol (ICP), was examined in binding assays with rat liver plasma membrane (LPM). ICP demonstrated both a higher specificity and a greater affinity for $\beta$-adrenergic receptors than any previously available $\beta$ adrenergic radioligand used to study rat LPM. Utilizing this new ligand it was found that $\beta$-adrenergic receptor density decreased from $114 \pm 4 \mathrm{fmol} \mathrm{mg}^{-1}$ in newborn LPM to $19 \pm 3 \mathrm{fmol} \mathrm{mg}^{-1}$ in adult male LPM. In contrast $\alpha$-adrenergic receptor density examined using ${ }^{3} \mathrm{H}$-prazosin increased from $161 \pm 14 \mathrm{fmol} \mathrm{mg}^{-1}$ in the newborn to 554 $\pm 59 \mathrm{fmol} \mathrm{mg}^{-1}$ in the adult male. The results of ICP displacement assays employing various $\beta$-adrenergic agonsists and antagonists indicated that ICP binding sites were $\beta_{2}$-adrenergic receptors. Both guanosine triphosphate and its nonhydrolyzable synthetic analog guanylyl-imidodiphosphate lowered the affinity of epinephrine for ICP binding sites similarly in newborn and adult LPM. Thus the coupling of receptor to guanine nucleotide regulatory protein appeared to be the same in both age groups examined. In isolated hepatocytes glycogen phosphorylase activation was mediated by $\beta_{2}$-adrenergic stimuli in the newborn and predominantly $\alpha$-adrenergic stimuli in the adult male. These results suggest that the change in glycogen phosphorylase activation from $\beta$ - to predominantly $\alpha$-adrenergic mechanisms seen with maturation is related to changes in receptor density. (Pediatr Res 19:862-868, 1985
\end{abstract}

\author{
Abbreviations \\ cAMP, $3^{\prime}: 5^{\prime}$-cyclic adenosine monophosphate \\ GTP, guanosine triphosphate \\ Gpp(NH)p, guanylyl-imidodiphosphate \\ ICP, ${ }^{125}$ I-iodocyanopindolol \\ LPM, liver plasma membrane \\ $\mathrm{Kd}$, dissociation constant
}

The mechanism of action of epinephrine on liver glycogenolysis varies depending on a number of factors. In certain species such as the guinea pig and rabbit epinephrine-induced glycogenolysis is mediated by the $\beta$-adrenergic receptor system $(1,2)$ while in the adult male rat the $\alpha$-adrenergic system predominates (3, 4). In the adult female rat glycogenolysis has recently been shown to be under the influence of both $\alpha$ - and $\beta$-adrenergic stimuli (4). Several recent studies have also emphasized the importance of the age of the experimental animals on the adrenergic control of glycogenolysis. In these investigations it was demonstrated that $\beta$-adrenergic stimuli resulted in a marked rise in cAMP levels in hepatocytes from juvenile rats but little rise was noted in the hepatocytes from adult male rats. They also showed that glucose release from the cells occurred following both $\alpha$-and $\beta$-adrenergic stimuli in the juvenile hepatocytes but only following $\alpha$-adrenergic stimulation in the adult hepatocytes $(5,6)$. In another study using cultured fetal hepatocytes cAMP accumulation and glycogenolysis were mediated solely by $\beta$-adrenergic stimuli ( 7 ). However, the results of this study must be questioned since it has recently been reported that the culturing of adult male hepatocytes results in an increase in $\beta$-adrenergic receptor density and a changeover in adrenergic mediated glycogenolysis from $\alpha$ to $\beta$ control (8). Nonetheless, several of the latter studies seem 
to suggest that in rat liver the adrenergic control of glycogenolysis undergoes developmental changes; and it has been speculated that this maturational change from $\beta$ - to predominantly $\alpha$ adrenergic control may be related to changes in the number or more specifically density of adrenergic plasma membrane receptors. However, initial attempts by us and others (8) to characterize adequately the $\beta$-adrenergic receptor in rat LPM have been unsuccessful utilizing ${ }^{125}$ I-iodohydroxybenzylpindolol because of its high nonspecific binding. In the present study we utilized a new $\beta$-adrenergic radioligand, ICP, in binding assays to determine $\beta$-adrenergic receptor density in purified plasma membranes from newborn and adult male rats because at least in other species and tissues it has been shown to have a greater affinity and specificity for the $\beta$-adrenergic receptor than any previously available radioligands (9). $\alpha$-Adrenergic receptor density was also investigated in the same membrane preparations using ${ }^{3} \mathrm{H}$-prazosin. The results of binding assays on plasma membranes was then correlated with adrenergic stimulation of glycogen phosphorylase in isolated hepatocytes. Our results demonstrate that with maturation $\beta$-adrenergic receptor density decreases while $\alpha$-adrenergic receptor density increases. In addition the adrenergic stimulation of glycogen phosphorylase in isolated hepatocytes was mediated solely by the $\beta$-adrenergic system in the newborn and predominantly by the $\alpha$-adrenergic system in the adult male. These findings support the hypothesis that changes in plasma membrane receptor density are responsible for the maturational changes in the adrenergic control of glycogenolysis. We also were able to show that ICP binding sites are $\beta_{2}$ subtype adrenergic receptors.

\section{MATERIALS AND METHODS}

Plasma Membrane preparation. Purified plasma membranes were prepared from the livers of Sprague-Dawley rats obtained from Sasco Inc. (St. Louis, MO) by the method of Neville (10) with slight modifications of several of the centrifugation steps. Animals were sacrificed by intraperitoneal pentobarbital in adults and decapitation in newborns. Pentobarbital did not effect receptor density or $\mathrm{Kd}$ in preliminary investigations in adult rats. The removed livers were immediately placed in ice cold $1.0 \mathrm{mM}$ $\mathrm{NaHCO}_{3}$ buffer. In the adult males, which were older than 60 days and weighed 195-265 g, $10 \mathrm{~g}$ of liver tissue from each animal was used in the preparation of each membrane. In the newborns aged 5-7 days weighing 12-16 g each the livers of eight to nine different animals from a given litter were pooled $(4-6 \mathrm{~g}$ total) in preparing each membrane. After weighing the livers were minced in 19 volumes of $1.0 \mathrm{mM} \mathrm{NaHCO}$ buffer and homogenized in a Dounce homogenizer by eight strokes with Pestle A. Each homogenate was filtered through one layer each of gauze and cheesecloth; and after removing samples for protein and 5 '-nucleotidase assays, $1.0 \mathrm{mM} \mathrm{NaHCO}_{3}$ was added to a final volume of $250 \mathrm{ml}$ which was well mixed and then centrifuged for $20 \mathrm{~min}$ at $3500 \times \mathrm{g}$. The pellets were added to approximately $11 \mathrm{ml}$ of $69 \%(\mathrm{w} / \mathrm{w})$ sucrose and then adjusted to a final sucrose concentration of $44 \%$ by the addition of either more $69 \%$ sucrose or buffer solution. Fifteen to twenty milliliters of $42.3 \%(\mathrm{w} / \mathrm{w})$ sucrose was carefully layered over the resuspended pellets and the samples centrifuged at $4^{\circ} \mathrm{C}$ in a Beckman SW 27 roter for $2 \mathrm{~h}$ at $90,000 \times g$. The membrane which floated on top of the $42.3 \%$ sucrose layer were removed, mixed gently in $25 \mathrm{ml}$ of the buffer solution, and centrifuged at $15,000 \times g$ for $20 \mathrm{~min}$. The pellets were then resuspended in $3-5 \mathrm{ml}$ of the buffer which yielded a final protein concentration of $2-6 \mathrm{mg} / \mathrm{ml}$ as determined by the method of Lowry et al. (11) using bovine serum albumin as standard. Purification of the samples was assessed by determining protein recovery and 5 -nucleotidase activity as described by Wendell and Unkeless (12). Once prepared, membranes were immediately snap frozen in an acetonedry ice bath and then stored at $-60^{\circ} \mathrm{C}$ until used in binding assays. Under these conditions, the protein was stable for binding studies for at least 2 months.

Assay of ${ }^{125} I-I C P$ binding. Binding assays were carried out in duplicate or triplicate at $37^{\circ} \mathrm{C}$ by incubating membrane $(20-80$ $\mu \mathrm{g}$ ) in a final volume of $250 \mu \mathrm{l}$ of $10-50 \mathrm{mM} \mathrm{Mg}$-Tris buffer ( $\mathrm{pH}$ 7.4) and ICP and/or competing drugs for $1 \mathrm{~h}$. For ICP saturation studies the membrane protein was incubated with increasing final concentrations of ICP ranging from 20-300 pM. For ICP displacement studies membrane protein and ICP $(30 \mathrm{pM})$ were incubated with increasing concentrations of the competing ligand. Specific concentrations are noted in the legends of the appropriate figures. Reactions were terminated by the addition of $4 \mathrm{ml}$ of ice cold $\mathrm{Mg}$-Tris buffer and bound and free ligand were separated by rapid filtration through Whatman GF/B glass fiber filters (Whatman, Inc., Clifton, $N J$ ) which were then washed with an additional $12 \mathrm{ml}$ of the buffer. The filter discs were allowed to completely dry before the radioactivity was measured in a $\gamma$ counter at $80 \%$ efficiency (United Technologies Packard Auto-Gamma 500). Specific binding of the ICP was defined as the amount of the label bound in the absence of competing ligand minus the amount bound in the presence of $10^{-6} \mathrm{M}(-)$ alprenolol. Under the conditions employed specific binding was a linear function of the protein concentration and was consistently greater than $80 \%$ of total binding.

Assay of ${ }^{3} \mathrm{H}$-prazosin binding. Binding assays were carried out in duplicate at $25^{\circ} \mathrm{C}$ by incubating membrane $(20-80 \mathrm{ug})$ in a final volume of $1 \mathrm{ml}$ of $10-50 \mathrm{mM} \mathrm{Mg}$-Tris buffer $(\mathrm{pH} \mathrm{7.4)}$ and ${ }^{3} \mathrm{H}$-prazosin at a final concentration of $50-600 \mathrm{pM}$ for $30 \mathrm{~min}$. Termination of the assay and separation of bound from free ligand was done as described above for ICP. The dried discs were placed in $7 \mathrm{ml}$ of scintillation fluid in glass vials and the radioactivity measured in a beta counter (United Technologies Packard, Tri-Carb 460). Specific binding was defined as previously mentioned using $10^{-5} \mathrm{M}( \pm)$-phentolamine as the competing ligand and was consistently greater than $70 \%$ of total binding.

Hepatocyte preparation. Isolated hepatocytes were obtained by in vivo perfusion of the livers with a collagenase-containing Krebs-Ringer bicarbonate buffer $\mathrm{pH}$ 7.4. In the adult rats the livers were perfused according to the method of Berry (13). In the newborn rats in which the hepatocytes from two animals were pooled the method of Ferre et al. (14) was used. In this case the perfusate enters the liver via a 23 -gauge butterfly needle introduced into the inferior vena cava above the renal veins and exits via the severed portal vein. Cephalad flow of perfusate above the liver was avoided by ligation of the inferior vena cava below the heart. Collagenase $(35 \mathrm{mg} / 100 \mathrm{ml})$ and $0.102 \mathrm{M} \mathrm{CaCl}_{2}$ $(1.14 \mathrm{ml} / 100 \mathrm{ml})$ were added to the buffer only after the exiting perfusate was grossly free of blood and then the perfusion was allowed to continue for another $20-30 \mathrm{~min}$ during which time the perfusate was continually gassed with a $95 \%: 5 \% \quad \mathrm{O}_{2}: \mathrm{CO}_{2}$ mixture. The livers were then gently removed into a beaker containing the perfusion media and gently teased to release isolated hepatocytes. After filtering through cheesecloth and centrifugation at $60 \times g$ for $30 \mathrm{~s}$ to separate the parenchymal cells the pellet was resuspended in perfusion media in a flask into which a $95 \%: 5 \% \quad \mathrm{O}_{2}: \mathrm{CO}_{2}$ mixture was continuously introduced. The cells were then placed in a $37^{\circ} \mathrm{C}$ AquaTherm Water Bath Shaker (New Brunswick Scientific Company, Inc., Edison, NJ) at $100 \mathrm{rev} / \mathrm{min}$ for $60-90 \mathrm{~min}$ before being used. Viability of the hepatocytes was checked by Trypan blue exclusion immediately before and after stimulation studies and was routinely greater than $90 \%$. Cell concentration was $2-6 \times 10^{6}$ cells $/ \mathrm{ml}$ and contamination by nonparenchymal cells was consistently less than $10 \%$ as determined by light microscopy.

Phosphorylase a dose response assay. For the adult assays 500$\mu \mathrm{l}$ aliquots of the hepatocytes were incubated with either adrenergic agonists or agonists plus antagonists at $37^{\circ} \mathrm{C}$ in the water bath shaker. Stimulation was stopped at exactly 2 min by removing $200 \mu \mathrm{l}$ aliquots of the mixture into test tubes on ice as 
described by Hutson et al. (15). This period of time was chosen because in preliminary studies hormonal stimulation was maximal at $2 \mathrm{~min}$ in both newborn and adult hepatocytes. The cells were then homogenized for 10 seconds at half speeed on an Ultra-Turrax homogenizer (Tekmar Company, Cincinnati, OH). Newborn assays were performed identically except half volume aliquots were used. Phosphorylase $a$ activity was then determined in the stimulated hepatocytes by measuring the incorporation of ${ }^{14} \mathrm{C}-\mathrm{G}-1-\mathrm{P}$ into glycogen by the method of Gilboe et al. (16).

Materials. (-)-Epinephrine, (-)-norepinephrine, (-)-isoproterenol, (-)-alprenolol, and guanosine triphosphate were obtained from Sigma Chemical, St. Louis, MO; (-)-metroprolol and ( \pm )-phentolamine were from Ciba Pharmaceutical, Summit, $\mathrm{NJ}:{ }^{125}$ I-iodocyanopindolol and ${ }^{3} \mathrm{H}$-prazosin were obtained from New England Nuclear, Boston, MA; ${ }^{14} \mathrm{C}$-glucose-1-phosphate from Amersham International Ltd., Amersham, UK; guanylylimidodiphosphate was obtained from Boerhinger Mannheim, New York, NY; ( \pm )-epinephrine from Sterling Winthrop Research Institute, Rensselaer, NY: (-)-zinterol from Bristol Myers Company, Evansville, IN; and collagenase, type I from Worthington Pharmaceutical, Freehold, NJ.

\section{RESULTS}

Purification of the membranes was assessed by measuring protein recovery and $5^{\prime}$-nucleotidase activity and the results are presented in Table 1 . The findings suggest that while both aduit and newborn LPM were highly purified the degree of purification was slightly higher in the adult membrane preparations.

In order to determine appropriate conditions for binding assays

Table 1. Membrane purification*

\begin{tabular}{|c|c|c|}
\hline & Newborn & Adult \\
\hline $\begin{array}{l}\text { Protein in crude homogenate (mg } \\
\text { protein per } \mathrm{g} \text { wet liver) }\end{array}$ & $135 \pm 8 \mathrm{mg} / \mathrm{ml}$ & $162 \pm 16 \mathrm{mg} / \mathrm{ml}$ \\
\hline $\begin{array}{l}\% \text { protein recovery (crude ho- } \\
\text { mogenate to LPM) }\end{array}$ & $2.6 \pm 0.7 \%$ & $1.3 \pm 0.4 \%$ \\
\hline $\begin{array}{l}5^{\prime} \text {-Nucleotidase activity increase } \\
\text { (LPM vs crude homogenate) }\end{array}$ & $7 \pm 1$ times & $11 \pm 2$ times \\
\hline
\end{tabular}

* Results represent the mean \pm SE of five membrane preparations. and to evaluate ICP binding to rat liver plasma membrane preliminary studies were undertaken. Figure 1 describes the association-dissociation reaction of ICP with liver plasma membrane protein. It was found that equilibrium was reached within 40 min and although not shown in Figure 1 the amount of ICP bound remained the same beyond this point out until $4 \mathrm{~h}$ time. In this particular experiment the $\beta$-adrenergic antagonist (-)alprenolol was added to a final concentration of $10^{-6} \mathrm{M}$ at 40 min to examine the dissociation reaction. Insets $A$ and $B$ show logarithmic transformations of the specific binding data for the association and dissociation reactions respectively.

In order to determine if altering the protein concentration would affect ICP binding, $80 \mathrm{pM}$ final concentrations of the radioligand were incubated with various concentrations of membrane protein ranging from $0.04-0.32 \mathrm{mg} / \mathrm{ml}$ for $1 \mathrm{~h}$ at $37^{\circ} \mathrm{C}$. The results which are indicated in Figure 2 demonstrate that under the conditions employed specific binding of ICP to the membrane is directly proportional to protein concentration and represents greater than $85 \%$ of total binding.

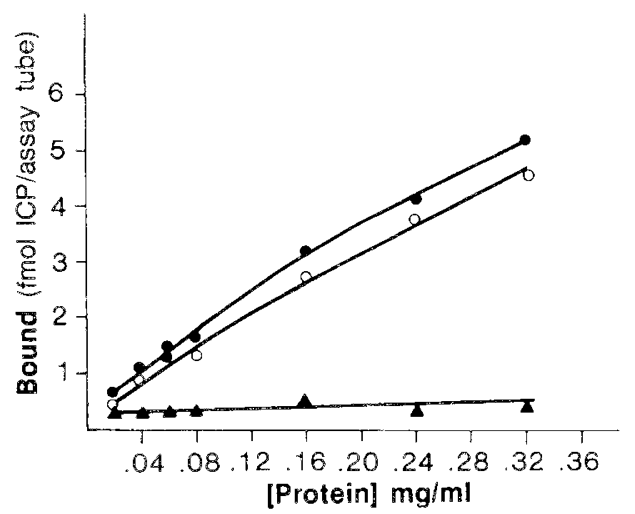

Fig. 2. ICP binding as a function of protein concentration. Eighty $\mathrm{pM}$ concentrations of ICP were incubated with protein concentrations ranging from 0.04 to $0.36 \mathrm{mg} / \mathrm{ml}$ for $1 \mathrm{~h}$ at $37^{\circ} \mathrm{C}$ in the absence (otal binding) and presence of $10^{-6} \mathrm{M}(-)$-alprenolol ( $\triangle$ nonspecific binding) for the determination of specific binding $(O)$. Data points are the means of triplicate determinations.

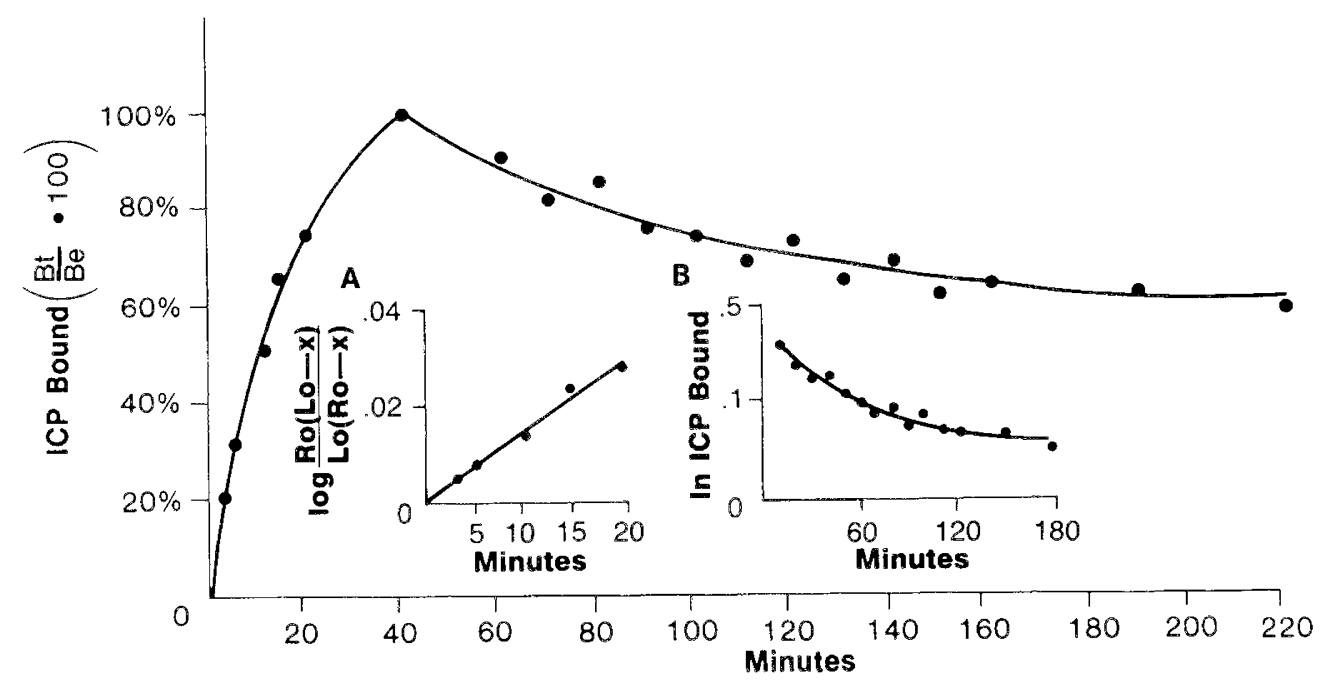

Fig. 1. Forward and reverse kinetics of ICP binding to newborn LPM. Membrane $(0.2 \mathrm{mg} / \mathrm{ml})$ and ligand $(30 \mathrm{pM})$ were incubated at $37^{\circ} \mathrm{C}$; and at $40 \mathrm{~min}(-)$-alprenolol was added to a final concentration of $10^{-6} \mathrm{M}$ to initiate the dissociation reaction. At the times indicated $250-\mu 1$ aliquots were removed in duplicate and assayed for bound ICP. $B_{t}$ represents amount of ICP bound at the given times while $B_{e}$ represents the amount bound at equilibrium. The inset $(A)$ is a logarithmic transformation of the binding data of the initial phase of the association reaction where (Ro) and (Lo) are unoccupied receptor and free ligand concentrations at the beginning of the reaction and $\{x\}$ is the concentration of bound ligand at time $t$. The association rate constant is determined from the slope of this line by the following equation Kon $=$ slope $(2.303) /[($ Lo $)-($ Ro $)]$. The inset $(B)$ shows In(ICYP) bound versus time. By nonlinear regression analysis $\mathrm{K}_{-1}$ and $\mathrm{K}_{-2}$ were determined (see text). 
In another study it was found that the addition of $( \pm)$-phentolamine at a final concentration of $10^{-5} \mathrm{M}$ had no affect on either specific or nonspecific binding of ICP to membrane (data not presented). This indicates that, unlike some other iodinated

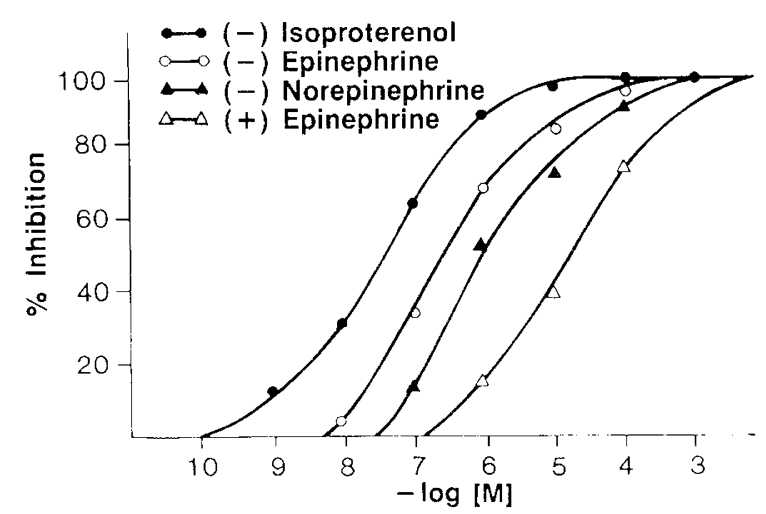

Fig. 3. Inhibition of ICP binding to newborn LPM by classical adrenergic agonists. Twenty to thirty $\mu \mathrm{g}$ of membrane protein was incubated with ICP $(30 \mathrm{pM})$ and concentrations of competing ligands ranging from $10^{-9}$ to $10^{-3} \mathrm{M}$ for $1 \mathrm{~h}$ at $37^{\circ} \mathrm{C}$. Data points are the mean of three experiments each done in triplicate.

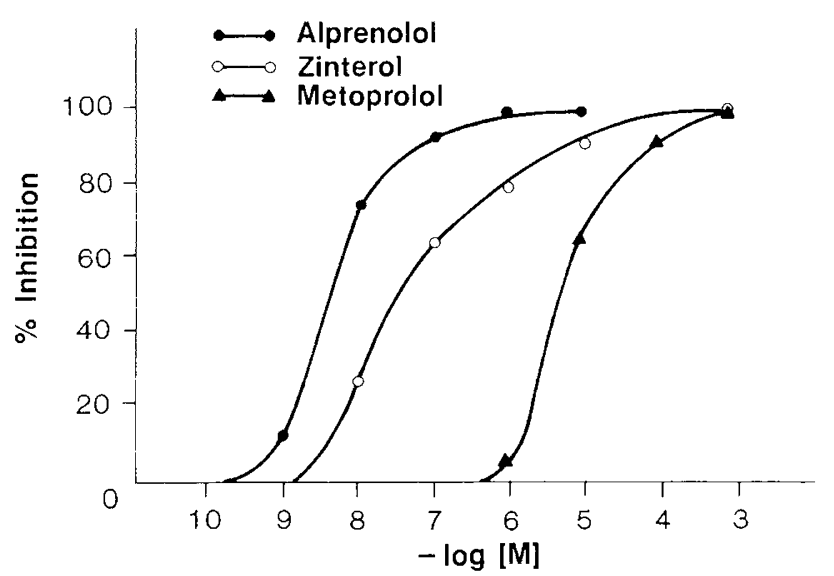

Fig. 4. Inhibition of ICP binding to newborn LPM by $\beta$-adrenergic ligands. Twenty to thirty $\mu \mathrm{g}$ of membrane protein was incubated with ICP $(30 \mathrm{pM})$ and concentrations of the competing ligand ranging from $10^{-9}$ to $10^{-3} \mathrm{M}$ for $1 \mathrm{~h}$ at $37^{\circ} \mathrm{C}$. Data points are the mean of three experiments each done in duplicate. $\beta$-adrenergic radioligands $(17,18)$, under the conditions employed in our binding assays ICP does not bind to $\alpha$-adrenergic receptors to any appreciable degree.

Further characterization of the ICP binding sites was determined by a number of displacement studies. As shown in Figure 3 the order of potency for displacing ICP from the membrane preparations was isoproterenol $>$ epinephrine $>$ norepinephrine which is typical for $\beta_{2}$-adrenergic receptors. The data in Figure 3 also demonstrates that ICP is stereoselectively displaced by the $(-)$ and $(+)$ forms of epinephrine.

That ICP binding sites are $\beta_{2}$-adrenergic receptors was further deduced by other displacement studies using subtype selective and nonselective $\beta$-adrenergic ligands (Fig. 4). It was found that alprenolol, a nonspecific $\beta$-adrenergic antagonist, was more effective in displacing ICP than zinterol, a $\beta_{2}$-adrenergic agonist, and approximately three orders of magnitude more effective than metoprolol, a $\beta_{1}$-adrenergic antagonist.

Inhibition of ICP binding by epinephrine was also investigated in the absence and presence of GTP and its nonhydrolyzable synthetic analog, $\mathrm{Gpp}(\mathrm{NH}) \mathrm{p}$. The addition of GTP resulted in a shift of the right in the ICP displacement curve (data not shown) and an increase in the Hill coefficient from 0.46 to 0.71 . Similar studies were also carried out using $\mathrm{Gpp}(\mathrm{NHp})$ in both adult and newborn membrane preparations (Fig. 5). In both the addition of the GTP analog resulted in a similar shift to the right in the displacement curve and increase in the Hill coefficient as was seen with GTP.

Table 2 summarizes the data obtained from ICP and ${ }^{3} \mathrm{H}$-prazosin saturation binding studies. $\mathrm{Kd}$ and receptor density $\left(B_{\max }\right)$ were determined from Scatchard plots of specific binding data, representative examples of which are shown in Figure 6. ICP ( $\beta$-adrenergic) binding sites declined significantly with age $\left(114 \pm 4 \mathrm{fmol} \mathrm{mg}^{-1}\right.$ in the newborns versus $19 \pm 3 \mathrm{fmol} \mathrm{mg}^{-1}$ in the adult) while ${ }^{3} \mathrm{H}$-prazosin ( $\alpha$-adrenergic) binding sites in-

Table 2. Summary of receptor binding in newborn and adult

\begin{tabular}{|c|c|c|c|c|c|c|}
\hline & \multirow[b]{2}{*}{$n$} & \multirow[b]{2}{*}{ Wt $(\mathrm{g})$} & \multicolumn{2}{|c|}{ iodocyanopindolol } & \multicolumn{2}{|c|}{${ }^{3} \mathrm{H}$-prazosin } \\
\hline & & & $\begin{array}{c}\mathrm{K}_{\mathrm{d}} \\
(\mathrm{pmol})\end{array}$ & $\begin{array}{c}\mathrm{B}_{\max } \\
(\mathrm{fmol} / \mathrm{mg})^{*}\end{array}$ & $\begin{array}{c}\mathrm{K}_{\mathrm{d}} \\
(\mathrm{pmol})\end{array}$ & $\underset{(\mathrm{fmol} / \mathrm{mg})^{*}}{\mathrm{~B}_{\max }}$ \\
\hline New & 5 & $12-16$ & $30 \pm 2$ & $114 \pm 4$ & $103 \pm 7$ & $161 \pm 14$ \\
\hline Adult & 5 & $195-265$ & $31 \pm 5$ & $19 \pm 3 \dagger$ & $58 \pm 11$ & $554 \pm 59 \ddagger$ \\
\hline
\end{tabular}

* fmol bound per mg purified LPM.

$\dagger$ Adult $<$ newborn $p<0.001$.

$\$$ Adult $>$ newborn $p<0.001$ by Student's $/$ test.
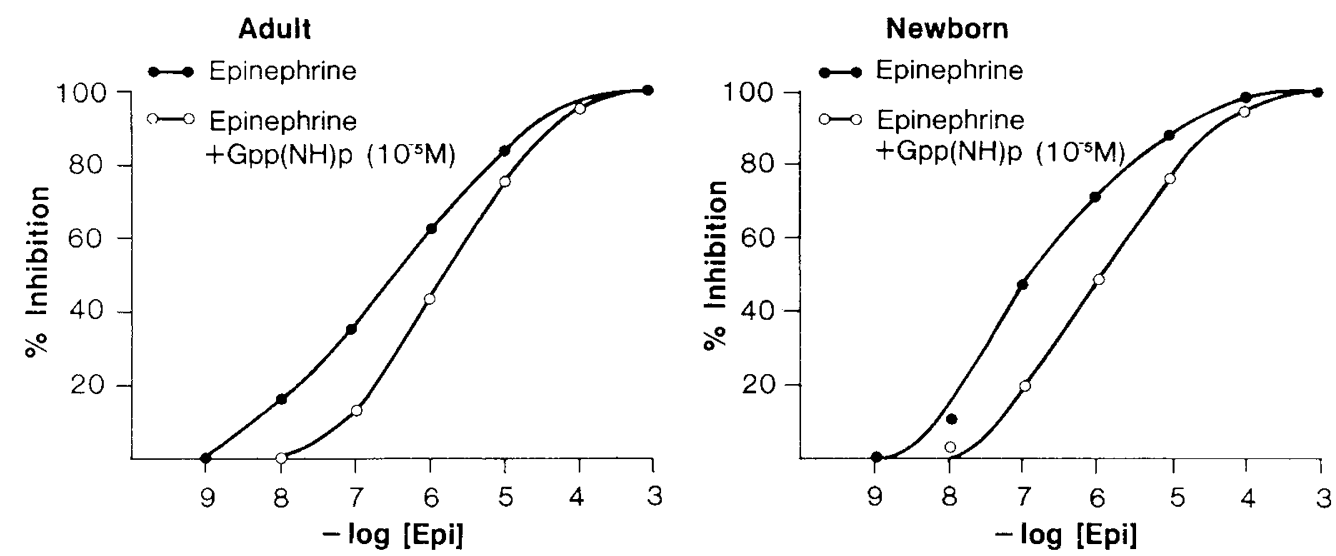

Fig. 5. Inhibition of ICP binding to newborn and adult LPM by epinephrine in the presence and absence of GPP(NH)p. Twenty to thirty $\mu \mathrm{g}$ of membrane protein was incubated in the presence $(O)$ and absence $(0)$ of $\mathrm{Gpp}(\mathrm{NH}) \mathrm{p}\left(10^{-5} \mathrm{M}\right)$ for $1 \mathrm{~h}$ at $37^{\circ} \mathrm{C}$. Data points are the mean of two to three experiments each done in duplicate or triplicate. 

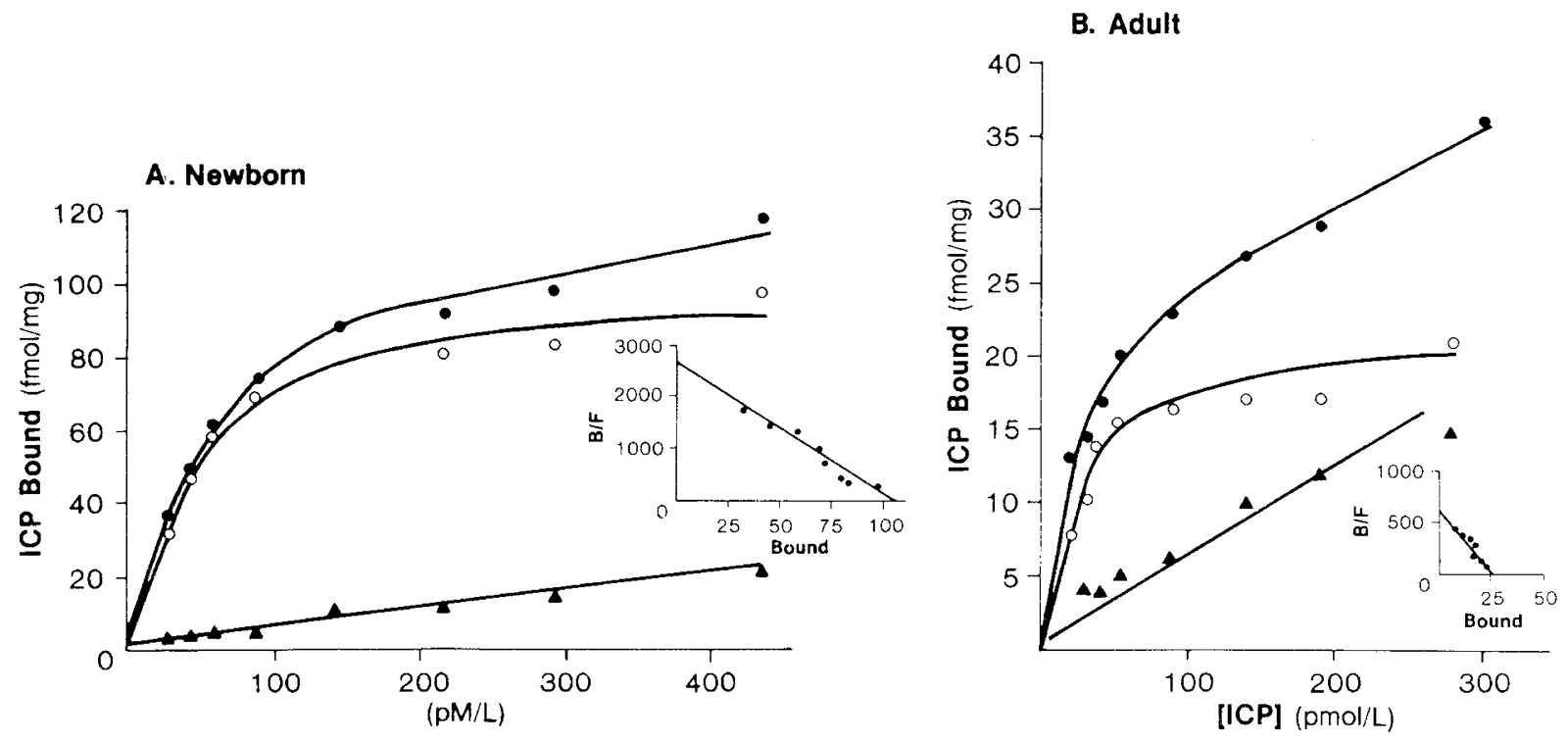

Fig. 6. Newborn and adult ICP saturation binding curves and Scatchard plots of specific binding data. Membrane protein $(0.2-0.3 \mathrm{mg} / \mathrm{ml})$ was incubated with increasing final concentrations of ICP ranging from $20-300 \mathrm{pM}$ for $1 \mathrm{~h}$ at $37^{\circ} \mathrm{C}$ in the absence ( $\bullet$ total binding) and presence of $10^{-6} \mathrm{M}(-)$-alprenolol ( $\triangle$ nonspecific binding) for the determination of specific binding $(O)$. Data points are the mean of triplicate determination at each ligand concentration. $B / F$, bound to free ligand concentration.

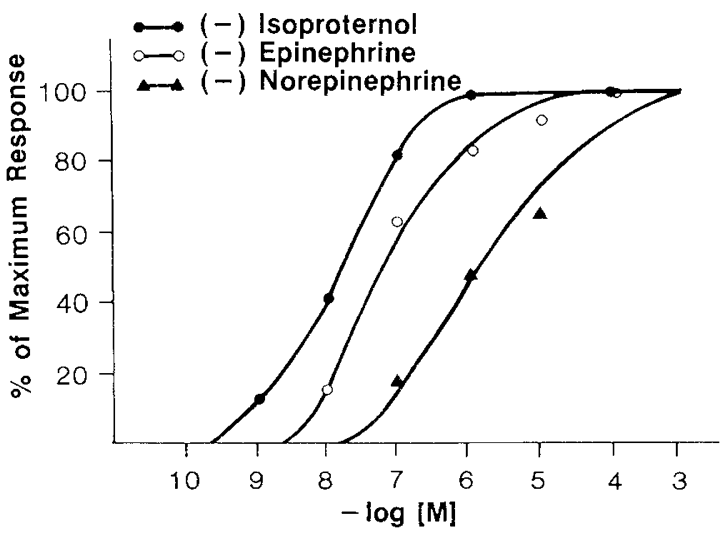

Fig. 7. Newborn glycogen phosphorylase dose response. Aliquots, 250 $\mu 1$, of isolated hepatocytes from 5 - to 7 -day-old rats were stimulated with either (-)-isoproterenol $(-(-)$-epinephrine $(O)$, or $(-)$-norepinephrine $(\triangle)$ in final concentrations ranging from $10^{-10}$ to $10^{-3} \mathrm{M}$ for $2 \mathrm{~min}$ at $37^{\circ} \mathrm{C}$. Results are expressed as percentage of maximum phosphorylase $a$ activity versus agonist concentration. Data points are means of four to five separatc experiments.

creased significantly $\left(161 \pm 14 \mathrm{fmol} \mathrm{mg}^{-1}\right.$ in the newborn versus $554 \pm 59 \mathrm{fmol} \mathrm{mg}^{-1}$ in the adult). The $\mathrm{Kd}$ value of approximately $30 \mathrm{pM}$ for ICP represents an affinity three to four times greater than any previously available iodinated $\beta$-adrenergic radioligand (9).

The glycogenolytic response of newborn hepatocytes to adrenergic stimulation was assessed by measuring phosphorylase $a$ activity and the results are presented in Figure 7. The order of potency for stimulating glycogen phosphorylase was isoproterenol $>$ epinephrine $>$ norepinephrine which is characteristic of $\beta_{2}$-adrenergic responsiveness. In another series of experiments the relative contributions of $\alpha$ - and $\beta$-adrenergic stimulation on glycogen phosphorylase in both newborn and adult hepatocytes was examined (Fig. 8). Hepatocytes were stimulated with a combination of (-)-epinephrine $\left(10^{-5} \mathrm{M}\right)$ and either $( \pm)$-phentolamine $\left(3 \times 10^{-5} \mathrm{M}\right)$ or $(-)$-alprenolol $\left(3 \times 10^{-5} \mathrm{M}\right)$ to represent either $\beta$-or $\alpha$-adrenergic stimulation, respectively. In the 5-day

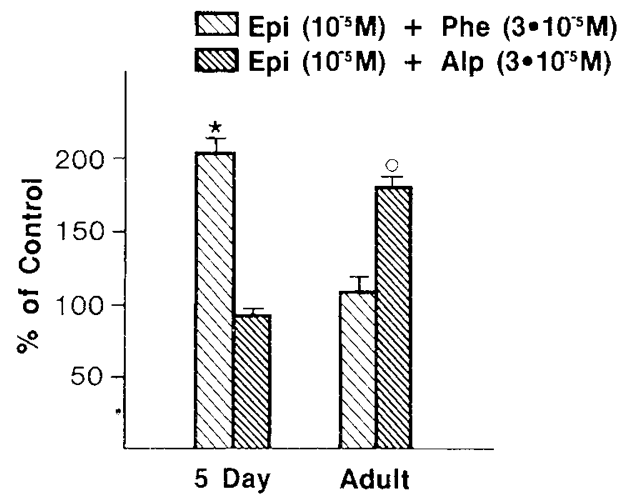

Fig. 8. $\alpha$ and $\beta$-Adrenergic stimulation of glycogen phosphorylase in newborn and adult hepatocytes. Isolated hepatocytes from 5-day and adult rats were stimulated with (-)-epinephrine $\left(10^{-5} \mathrm{M}\right)$ and either $( \pm)$ phentolamine $\left(3 \times 10^{-5} \mathrm{M}\right)$ to represent $\beta$-adrenergic stimulation or (-)alprenolol $\left(3 \times 10^{-5} \mathrm{M}\right)$ to represent $\alpha$-adrenergic stimulation for $2 \mathrm{~min}$ at $37^{\circ} \mathrm{C}$. Results are expressed as percentage of basal phosphorylase $a$ activity in the absence of stimulation. The data points are the mean \pm $\mathrm{SE}$ of six to eight experiments. * 5 day $>$ adult $p<0.01 \mathrm{O}$ adult $>5$ day $p<0.01$ by Student's $t$ test.

hepatocytes $\beta$-adrenergic stimulation resulted in an almost $100 \%$ increase above basal in phosphorylase $a$ activity but $\alpha$-adrenergic stimulation was without effect. In the adult male hepatocytes a significant rise in phosphorylase $a$ activity was only seen with $\alpha$-adrenergic stimulation.

\section{DISCUSSION}

Attempts to characterize adequately the $\beta$-adrenergic receptor in newborn rat purified LPM have been unsuccessful using previously available radioligands such as ${ }^{125}$ I-iodohydroxybenzylpindolol because of its high nonspecific binding (8). This radioligand has been reported to bind to serotonin sites in rat cerebral cortex (19) and much of its nonspecific binding can be eliminated in rat glioma cells by the addition of phentolamine, an $\alpha$-adrenergic antagonist $(17,18)$. In the present study we utilized a relatively new radioligand, ICP. Under the conditions 
employed in our assays this ligand demonstrated rapid, reversible, and stereoselective binding as well as a very high affinity (Kd of $30 \mathrm{pM}$ ) and specificity for $\beta$-adrenergic receptors. The biphasic nature and shallowness of the ICP dissociation reaction with the addition of antagonist have been observed elsewhere (9). The calculations of the dissociation rate constants are based on the assumption that there are interconvertible receptor conformations resulting in a rapidly formed ICP-receptor complex which can dissociate quickly and a thermodynamically favored ICP-receptor complex that dissociates more slowly as postulated by Engel et al. (9) The high affinity and specificity of ICP binding made it possible to demonstrate that there was a significant decline in $\beta$-adrenergic receptor density in LPM seen with maturation of the male rat. In addition we were able to determine that ICP binding sites in newborn LPM were $\beta_{2}$-adrenergic receptors. The $\alpha$-adrenergic receptor was also examined in these same membranes and it was found that concomitant to the decline in $\beta$-adrenergic receptor density there was an increase in $\alpha$-adrenergic receptor density as measured by ${ }^{3} \mathrm{H}$-prazosin binding sites. To our knowledge only one other study has been published which specifically examined developmental changes in adrenergic receptor density in rat liver (20). $\beta$-Adrenergic receptors were studied using ${ }^{125}$ I-pindolol and $\alpha$-adrenergic receptors using ${ }^{3} \mathrm{H}$-prazosin and ${ }^{3} \mathrm{H}$-rauwolscine. Although the receptor densities in the study were much lower than ours large increases in $\alpha$-adrenergic receptor densities and decreases in $\beta$-adrenergic receptor densities with maturation were also noted. The lower numbers in the report are most likely due to the fact that a less purified membrane preparation was employed. In addition the reported $\mathrm{Kd}$ value for ${ }^{3} \mathrm{H}$-prazosin binding was at least an order of magnitude larger than what we found in the present study and in previous studies (21). A recent study (11) employing ICP and adult male LPM of similar purity as ours but prepared by an entirely different procedure reported a $\beta$-adrenergic density virtually identical to that reported here; and although no actual data were presented they stated that the receptor density was much higher in newborn LPM. Our studies on isolated hepatocytes revealed that the activation of glycogen phosphorylase by epinephrine was mediated exclusively by $\beta_{2}$ adrenergic mechanisms in the newborn and predominantly by $\alpha$-adrenergic mechanisms in the adult. Thus it appears that the $\beta$-adrenergic control of glycogenolysis which develops during fetal life (7) is carried over into the neonatal period; and only after this time does attentuation of the $\beta$-adrenergic response and emergence of the $\alpha$-adrenergic response occur (3-6). Much data have been accumulating which suggest that the low $\beta$-adrenergic receptor density in the adult male is responsible for the lack of a $\beta$-adrenergic glycogen phosphorylase activation. In the present study the coupling mechanism between receptor and guanyl nucleotide regulatory protein seemed to be the same in both newborn and adult membrane preparations since the addition of GTP and Gpp(NH)p in competition assays resulted in a shift to the right and an increase in the Hill coefficient of the displacement curves. Recently Nakamura et al. (8) have demonstrated the presence of both subunits of guanyl nucleotide regulatory protein in adult male hepatocytes and found that the addition of GTP did not increase adenyl cyclase activity in response to isoproterenol. We (22) and others (6) have also found that, although $\beta$-adrenergic stimulation produces only a small rise in cAMP accumulation in adult male hepatocytes, glucagon produces a rise in cAMP and glycogen phosphorylase activity which is similar to that seen in the newborn. These findings when taken together suggest that the most likely explanation for the lack of $\beta$-adrenergic responsiveness in adult male hepatocytes is the decreased receptor density since all of the other components of the $\beta$-adrenergic-mediated glycogen phosphorylase activation pathway are present and apparently functional. The significance of the developmental changes in rat liver adrenergic responsiveness with development is not clear at present. The cell surface adrenergic receptors may be activated by circulating epinephrine, norepinephrine, or locally released norepinephrine upon sympathetic nerve stimulation. Innervation of the rat liver is restricted to primarily vessels in the portal space and hilus $(23,24)$ as opposed to guinea pig, cat, primates, and humans where adrenergic nerves penetrate deep into the parenchyma (23-25). However, there is evidence that glucose output from the liver is directly regulated by the sympathetic nervous system in the rat (26). The development of hepatic innervation in the rat has not been reported to our knowledge and it remains to be studied whether the adrenergic receptor responsiveness changes are related to the developmental changes in innervation. While functionally unimportant in the adult rat, $\beta$-adrenergic control of glycogenolysis in the newborn may be essential in maintaining glucose homeostasis. As we have demonstrated, although $\alpha$-adrenergic receptors are present in the newborn hepatocyte in concentrations even greater than $\beta$-adrenergic receptors, their stimulation does not lead to a rise in glycogen phosphorylase activity. In addition sensitivity of the liver to glucagon, the other major hormone involved in glucose homeostasis, is apparently less in the newborn than in the adult (27).

In summary we conclude that 1) ICP appears to be a very useful radioligand for examining the $\beta$-adrenergic receptor in rat hepatocytes and probably other tissues and species as well, 2) rat liver ICP binding sites are $\beta_{2}$-adrenergic receptors, and 3 ) the maturational change in adrenergic-mediated glycogen phosphorylase activation from $\beta$ - to predominantly $\alpha$-adrenergic control is probably related to concomitant changes in the respective receptor densities.

\section{REFERENCES}

1. Arinze IJ, Kawai Y 1983 Adrenergic regulation of glycogenolysis in isolated guinea pig hepatocytes: evidence that $\beta_{2}$-receptors mediate catecholamine stimulation of glycogenolysis. Arch Biochem Biophys 225:196-202

2. Yorek MA, Rufo GA, Ray PD 1980 Gluconeogenesis in rabbit liver. Biochem Biophys Acta 632:517-526

3. Sherline P, Lynch A, Glinsmann WH 1972 Cyclic AMP and adrenergic receptor control of rat liver glycogen metabolism. Endocrinology 91:680 690

4. Studer RK, Borle AB 1982 Differences between male and female rats in the regulation of hepatic glycogenolysis. J Biol Chem 257:7987-7993

5. Blair JB, James ME, Roster JL 1979 Adrenergic control of glucose output and adenosine $3^{\prime}, 5^{\prime}$-monophosphate levels in hepatocytes from juvenile and adult rats. J Biol Chem 254:7579-7584

6. Morgan NG, Blackmore PF, Exton JH 1983 Age-related changes in the control of hepatic cyclic AMP levels by $\alpha_{1}$ and $\beta_{2}$-adrenergic receptors in male rats. J Biol Chem 258:5103-5109

7. Moncany ML, Plas C 1980 Interaction of glucagon and epinephrine in the regulation of adenosine $3^{\prime}, 5^{\prime}$-monophosphate-dependent glycogenolysis in the cultured fetal hepatocyte. Endocrinology 107:1667-1675

8. Nakamura $T$, Tomomura A, Noda C, Shimoji M, Ichihara A 1983 Acquisition of a $\beta$-adrenergic response by adult rat hepatocytes during primary culture. J Biol Chem 258:9283-9289

9. Engel G, Hoyer D, Berthold R, Wagner H 1981 (+) [ ${ }^{125}$ Iodo] cyanopindolol, a new ligand for $\beta$-adrenoreceptors in guinea pig. Naunyn Schmeiderbergs Arch Pharmacol 317:277-285

10. Neville DM 1968 Isolation of an organ specific protein antigen from cell surface membrane of rat liver. Biochem Biophys Acta 154:540-552

11. Lowry OH, Rosebrough NH, Farr AL, Randall RJ 1951 Protein measurement with the folin phenol reagent. J Biol Chem 193:265-275

12. Wendell CC, Unkeless JC 1969 Partial purification of a lipoprotein with 5'. nucleotidase activity from membranes of rat liver cells. Proc Natl Acad Sci USA 61:1050-1057

13. Berry MN 1974 High-yield preparation of morphologically intact isolated parenchymal cells from rat liver. Meth Enzymol 32:625-631

14. Ferré P, Satabin P, Manoubi LE. Callikan S, Girard J 1981 Relationship between ketogenesis and gluconeogenesis in isolated hepatocytes from new. born rats. Biochem J 200:429-433

15. Hutson NJ, Brumley Fr, Assimacopoulos FD, Harper S, Exton JH 1976 Studies on the adrenergic activation of hepatic glucose output. Studies on the $\alpha$-adrenergic activation of phosphorylase and inactivation of glycogen snythase in isolated rat liver parenchymal cells. J Biol Chem 251:5200-5208

16. Gilboe DP, Larson KL, Nutall FQ 1972 Radioactive method for the assay of glycogen phosphorylase. Anal Bochem 47:20-27

17. Terasaki WL, Brooker G $1978{ }^{125}$ I-iodohydroxybenzylpindolol binding sites on intact rat glioma cells: evidence for $\beta$-adrenergic receptors of high coupling efficiency. J Biol Chem 253:5418-5425

18. Schmitt $H$, Pochet $R 1977$ In vivo labelling of $\beta$-adrenergic receptors on rat glioma cells. FEBS Lett 76:302-305 
19. Dickinson KEJ. Nahorski SR. Willcocks AL 1981 Serotonin recognition sites are labelled in cerebral cortex by the $\beta$-adrenoreceptor antagonist ${ }^{125} \mathrm{I}$ hydroxubenzylpindolol. Br J Pharmacol 72:165P

20. McMillian MK, Schanberg SM, Kuhn CM 1983 Ontogeny of rat hepatic adrenoreceptors. J Pharmacol Exp Ther 227:181-186

21. Noguchi A 1983 Normal ontogeny of $x_{1}$ adrenergic receptor in rat liver is thyroid hormone dependent. Fndocrinology 113:672-676

22. Noguchi A. Jett PA. Gold $A$ H cAMP independent stimulation of glycogen phosphorylase in newborn rat hepatocytes. Am J Physiol 248:E560-E566

23. Metz. W. Forssman WG 1980 Innervation of the liver in guinea pig and rat. Anat Embrvol 160:239-252
24. Reilly FD, McCuskey PA. McCuskey RS 1978 Intrahepatic distribution of nerves in the rat. Anat Rec 191:55-68

25. Forssman WG, Ito $\mathrm{S} 1977$ Hepatocyte innervation in primates. J Cell Biol $74: 299-313$

26. Hartman H, Beckh K, Jungermann K 1982 Direct control of glycogen metabolism in the perfused rat liver by the sympathetic innervation. Eur J Biochem 123:521-526

27. Blazques E, Rubalcava B, Montesano R, Orci L, Unger RH 1976 Development of insulin and glucagon binding and the adenylate cyclase response in liver membranes of prenatal, postnatal, and adult rat: evidence of glucagon "resistance." Endocrinology 98:1014-1023

\title{
Differential Toxicity of RCA II $_{\text {(Ricin) on Rabbit }}$ Intestinal Epithelium in Relation to Postnatal Maturation ${ }^{1}$
}

\author{
ALLAN D. OLSON, THEODORE J. PYSHER, ALFREDO LARROSA-HARO, AKHTAR MAHMOOD, \\ AND RAMON TORRES-PINEDO
}

University of Oklahoma Health Sciences Center, Department of Pediatrics and Department of Pathology, Section of Pediatric Gastroenterology: and Nutrition, Oklahoma City, Oklahoma 73126

\begin{abstract}
The purpose of this work was to assess the toxic lectin ricin $\left(\mathrm{RCA}_{11}\right)$ as a probe for the study of intestinal permeability in the developing small bowel. Jejunal explants from suckling and adult rabbits were exposed to varying dosages of $\mathrm{RCA}_{\mathrm{IY}}$ for $30 \mathrm{~min}$ at $25^{\circ} \mathrm{C}$ and then cultured in toxin-free medium. The $\mathrm{RCA}_{1 I}$ dose required to inhibit protein synthesis during $6 \mathrm{~h}$ of culture increased from $0.1 \mu \mathrm{g} / \mathrm{ml}$ in 4-day-old rabbits to $25 \mu \mathrm{g} / \mathrm{ml}$ in weanling rabbits. $\mathrm{RCA}_{\mathrm{II}}$ cytotoxicity was almost completely blocked by $0.1 \mathrm{M}$ lactulose in all age groups. The kinetics of ${ }^{125} \mathrm{I}-\mathrm{RCA} A_{I I}$ binding to purified microvillus membranes were determined by incubating a fixed concentration of membrane protein $(30 \mu \mathrm{g})$ with increasing concentrations of labeled lectin $(2-18 \mu \mathrm{g} / \mathrm{ml})$. Binding attained saturation with adult but not with suckling animal membranes. The latter yielded a curvilinear relationship in Scatchard plots, suggesting either several classes of binding sites or negative cooperativity. $\mathrm{RCA}$ II binding was confined to the delipidated fraction of the membranes and decreased by $42 \%$ from 6 days old to adult age. The extreme sensitivity of colostral epithelium to $\mathrm{RCA}_{\mathrm{II}}$ is probably related to the high level of endocytosis exhibited by the immature membrane of suckling rabbits. The development of increasing resistance to the toxin, and associated decrease in binding, might be related to disappearance of saccharide sites in productive surface receptors occurring in the developmental course of intestinal glycosylation. (Pediatr Res 19: $868-872,1985$ )
\end{abstract}

Received January 7. 1985: accepted March 26. 1985.

Requests for reprints Ramon Torres-Pincdo. M.D. Professor of Pediatrics, P.O. Box 26307. Oklahoma City, OK 73126

Supported by Grant HD-12441 from the National Institute of Health

Presented in part at the annual meeting of the American Pediatric Society and the Society for Pediatric Research. Washington, D.C.. May 3-6. 1983

\author{
Abbreviations \\ $\mathrm{RCA}_{11}$, ricin \\ PBS, phosphate-buffered saline
}

The early part of the suckling period in rodents is characterized by a high level of receptor-mediated responses in small intestinal epithelium. This has been clearly shown for the jejunal transport of breast milk immunoglobulin $(1,2)$ and is also inferred from the high content of trophic factors in breast milk $(3,4)$. The surface characteristics underlying this high receptor responsiveness in the intestine of neonatal animals are poorly understood. A marked developmental change in surface reactivities to lectins has been described in the small intestine of suckling rats (5-7). In this animal species, the intestinal microvillus membrane undergoes a progressive shift from sialylation to fucosylation of glycoproteins and glycolipids during postnatal development (7). In the present work, we have examined the response of rabbit intestinal epithelium to the toxic action of $\mathrm{RCA}_{\mathrm{II}}$. This toxin inhibits protein synthesis in intact cells $(8,9)$ through a mechanism that requires terminal nonreducing galactosyl (or $\mathrm{N}$-acetylgalactosaminyl) residues (10) in a glycoprotein receptor capable of transmembrane signaling for toxin internalization (11). This toxin, therefore, "mimics" the mechanism of interaction of trophic hormones (12). The $\mathrm{RCA}_{\| I}$ membrane receptors may be part or be closely associated with cell surface components involved in cell-macromolecule and cell-cell recognition (13). The probing of intestinal epithelium with $\mathrm{RCA}_{\mathrm{II}}$ may provide insight into the role of glycosylation on receptor-mediated responses in the developing small bowel. 